\title{
A single major gene controls most of the difference in susceptibility to streptozotocin-induced diabetes between $\mathrm{C} 57 \mathrm{BL} / 6 \mathrm{~J}$ and $\mathrm{C3H} / \mathrm{HeJ}$ mice
}

\author{
K. Kaku ${ }^{1}$, J.McGill ${ }^{1}$, M. Province ${ }^{2}$ and M.A.Permutt ${ }^{1}$ \\ 1 Metabolism Division, Department of Internal Medicine, and \\ 2 Division of Biostatistics, Department of Preventive Medicine, Washington University School of Medicine, St. Louis, Missouri, USA
}

\begin{abstract}
Summary. To assess genetic factors determining sensitivity to streptozotocin-induced diabetes in inbred strains of mice, a genetic analysis of streptozotocin-sensitive $\mathrm{C} 57 \mathrm{BL} / 6 \mathrm{~J}$ and streptozotocin-resistant $\mathrm{C} 3 \mathrm{H} / \mathrm{HeJ}$ mice was performed. One week after a single dose of streptozotocin $(200 \mathrm{mg} / \mathrm{kg}$ body weight), differences in plasma glucose concentration were marked between male mice of the $\mathrm{C} 57 \mathrm{BL} / 6 \mathrm{~J}$ and $\mathrm{C} 3 \mathrm{H} / \mathrm{HeJ}$ strains $(p<0.001)$. To determine the number of genes responsible for the difference, $F_{1}$ male progeny of a cross between parental strains were produced, and found to be streptozotocin resistant like $\mathrm{C} 3 \mathrm{H} / \mathrm{HeJ}$ parents. $\mathrm{F}_{1}$ mice were, therefore, backcrossed with streptozotocin-sensitive $\mathrm{C} 57 \mathrm{BL} / 6 \mathrm{~J}$ mice

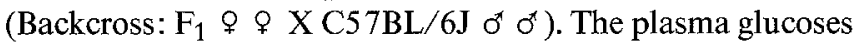
of backcrossed male mice $(n=41)$ following streptozotocin treatment appeared to segregate into two populations, half like the $\mathrm{C} 57 \mathrm{BL} / 6 \mathrm{~J}$ parent, and half like the $\mathrm{F}_{1}$ parent. Statisti$\mathrm{cal}$ analysis of the data revealed that the data fit a model with two distributions better than one with a single distribution,
\end{abstract}

suggesting a single major gene responsible for the difference in streptozotocin susceptibility. This hypothesis was also supported by the observation that streptozotocin sensitivity in 12 recombinant inbred strains of $\mathrm{C} 57 \mathrm{BL} / 6 \mathrm{~J}$ and $\mathrm{C} 3 \mathrm{H} / \mathrm{HeJ}$ mice appeared to segregate into two classes. Resistance to streptozotocin induced diabetes in $F_{1}$ mice suggested that the expression of this gene is recessive, although $\mathrm{X}$-chromosome linked inheritance could not be excluded.

Efforts to map the streptozotocin-sensitivity gene revealed lack of right linkage to several loci including the $\mathrm{H}-2$ locus. If inherited differences in the ability to resist a B-cell toxin play a role in genetic susceptibility to diabetes in man, then mapping the streptozotocin-susceptibility gene in mice may provide a means to evaluate the role of a putative homologous locus in the aetiology of diabetes in man.

Key words: Streptozotocin, diabetes-susceptibility, genetic analysis, inbred mouse strains, $\mathrm{H}-2$ locus.
Streptozotocin (SZ)-induced diabetes is mediated by pancreatic B-cell destruction accompanied by progressively severe hyperglycaemia [1-4]. The drug, a glucosamine-nitrosourea compound with significant antimicrobial $[5,6]$ and antitumor activity [7] as well as a potent diabetogenic effect [8], spontaneously decomposes to reactive methylcarbonium ions that alkylate DNA and produce interstrand crosslinks [9]. The diabetogenic effect may be related to the B-cell depletion of nicotinamide adenine dinucleotide, as diabetes can be prevented by concomitant nicotinamide administration $[10,11]$. The diabetogenic effects of SZ are also related to its glocosamine configuration as the drug is preferentially taken up by B cells relative to methylnitrosourea [12].

Inbred strains of mice showed varying susceptibility to the diabetogenic effects of SZ, administered either as a single dose or as multiple subdiabetogenic doses, indicating the importance of genetic background in the pathogenesis of SZ-induced diabetes [3,13]. Male mice are more sensitive than female mice [14-16], and the explanation for this important sexual dimorphism has yet to be determined. For male mice of different strains, however, there is a prominent difference in SZ-sensitivity, and the genetic loci involved have not been defined. Linkage of immune response genes within the major histocompatibility locus (H-2) has been suggested [17-19], but this finding is still uncertain [20-22]. Rossini et al. noted that a single high dose injection of SZ induced a remarkable hyperglycaemia in $\mathrm{C} 57 \mathrm{BL} / 6 \mathrm{~J}$ mice, while the same dose failed to produce diabetes in the $\mathrm{C} 3 \mathrm{H} / \mathrm{HeJ}$ strain [3]. In the present study, the number of modifying genes for SZ-susceptibility was assessed by measuring the effects of the drug in $F_{1}$ hybrids 


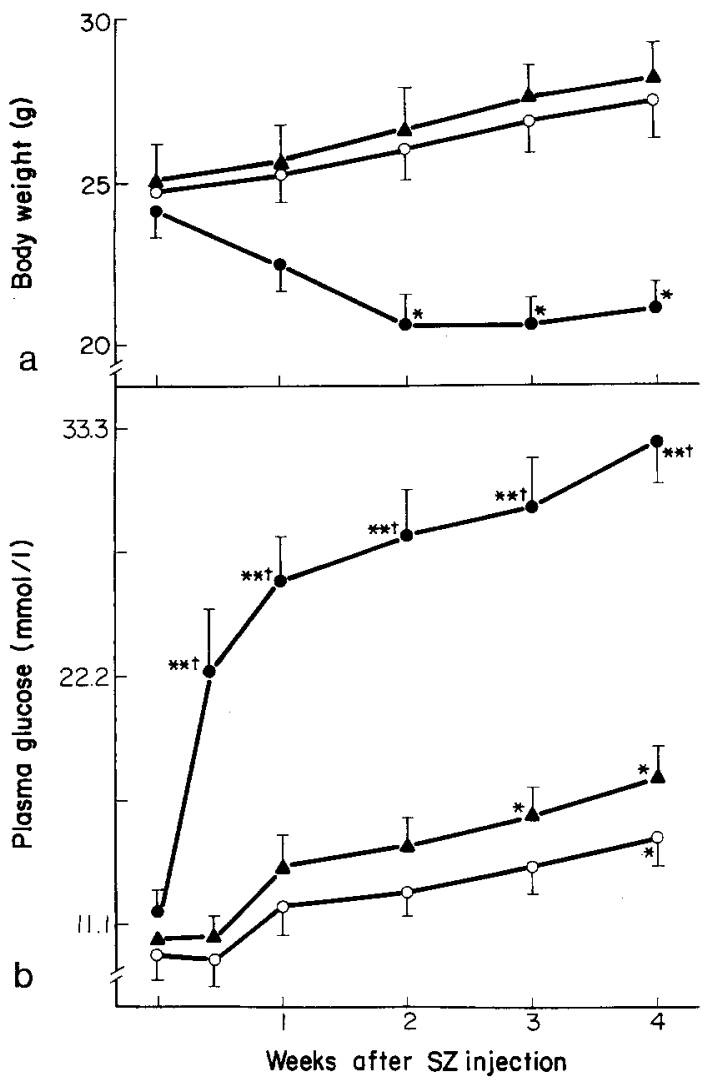

Fig. $1 \mathrm{a}$ and b. Body weight and plasma glucose of C57BL/6J (@), $\mathrm{C} 3 \mathrm{H} / \mathrm{HeJ}(\mathrm{o})$ and $\mathrm{F}_{1}$ hybrid $(\boldsymbol{\Delta})$ mice at various times after streptozotocin (SZ) administration $(200 \mathrm{mg} / \mathrm{kg}$ ) as described in Methods. Values are mean \pm SEM $(n=15)$ for each group. $* p<0.05$; ** $p<0.001$ compared with values before SZ treatment. $\dagger p<0.001$ compared with the value of $F_{1}$ mice

and backcrossed mice, as well as in established recombinant inbred strains of $\mathrm{C} 57 \mathrm{BL} / 6 \mathrm{~J} \mathrm{X} \mathrm{C3H/HeJ}$ mice $(\mathrm{BxH})$ [23]. The results of these studies suggest that an allelic difference at one major locus is responsible for most of the difference in SZ susceptibility noted between the two strains.

\section{Materials and methods}

\section{Animals}

Mice were obtained from the Jackson Laboratories, Bar Harbor, Maine, USA. The mice were given free access to tap water and chow (Purina Rodent Chow, Ralston-Purina, St.Louis, Mo., USA) throughout the experiment. To avoid the effect associated with gender differences in pathogenesis of SZ-induced diabetes [14-16] male $\mathrm{C} 57 \mathrm{BL} / 6 \mathrm{~J}$ mice were bred with female $\mathrm{C} 3 \mathrm{H} / \mathrm{HeJ}$ mice to obtain $\mathrm{F}_{1}$ hybrids, and for backcrossed mice, male $\mathrm{C} 57 \mathrm{BL} / 6 \mathrm{~J}$ mice were bred with female $F_{1}$ mice. Male mice were used exclusively for analysis. All mice were 5-8 weeks of age at the time of experimentation.

\section{Streptozotocin treatment}

SZ was purchased from Sigma, St. Louis, Missouri, USA. SZ was dissolved in a sterile $0.1 \mathrm{~mol} / \mathrm{l}$ sodium citrate, $\mathrm{pH} 4.5$, and injected i.p. within $5 \mathrm{~min}$ after preparation. Responses to different doses are presented in Results. All control mice were given injections with citrate buffer alone.

\section{Plasma glucose determination and intraperitoneal glucose tolerance test}

Whole blood $(250 \mu \mathrm{l})$ collected from the retro-orbital sinus of all nonfasted animals between $09.00-11.00$ hours using heparin-treated capillary tubes was analysed for plasma glucose concentration with a Beckman Glucose Analyzer II (Beckman Instruments, Inc., Arlington Heights, Ill., USA).

Intraperitoneal glucose tolerance testing (IPGTT) was performed after fasting overnight ( $18 \mathrm{~h}$ ) to characterize glucose tolerance of mice are described previously [24]. During the IPGTT, the most marked difference in plasma glucose had been noted at $30 \mathrm{~min}(\mathrm{C} 57 \mathrm{BL} / 6 \mathrm{~J}$, $26.9 \pm 1.6 \mathrm{mmol} / 1$ vs $\mathrm{C} 3 \mathrm{H} / \mathrm{HeJ}, 12.5 \pm 1.1 \mathrm{mmol} / 1, p<0.001)$, so blood samples were obtained at $30 \mathrm{~min}$ after the injection of glucose ( $2 \mathrm{~g} / \mathrm{kg}$ body weight).

\section{Determination of restriction fragment length polymorphisms at the $H-2$ locus and polymorphic forms of r-glutamyl myelotransferase}

To define the H-2 haplotypes of the parental strains of mice, restriction fragment length polymorphisms (RFLPs) were analysed in DNA from $\mathrm{C} 3 \mathrm{H} / \mathrm{HeJ}\left(\mathrm{H}-2^{\mathrm{k}}\right)$ and $\mathrm{C} 57 \mathrm{BL} / 6 \mathrm{~J}\left(\mathrm{H}-2^{\mathrm{b}}\right)$ mice. DNA was $\mathrm{di}-$ gested with Apa I, Bam HI, Dra I, Hind III, Kpn I, Pst I, Pvu II, and Taq I, and analysed by Southern blotting with a murine class II genomic probe IA as described [25].

Polymorphic r-glytamyl myelotransferase enzymic forms characteristic of $\mathrm{C} 57 \mathrm{BL} / 6 \mathrm{~J}$ and $\mathrm{C} 3 \mathrm{H} / \mathrm{HeJ}$ were determined by agarose gel electrophoresis of liver extracts according to the method of Tulchin and Taylor [27].

\section{Statistical analysis}

All results are expressed as mean \pm SEM. Student's $t$-tests (two-tailed) were employed to compare differences between the measures. Correlation coefficients $(r)$ were employed to assess the significance of linear relationship between continuous measurements. $p$-values are reported as measures of statistical significance.

Table 1. Plasma glucose concentrations (mean \pm SEM) one week following a single injection of various doses of streptozotocin in $\mathrm{C} 3 \mathrm{H} / \mathrm{HeJ}, \mathrm{C} 57 \mathrm{BL} / 6 \mathrm{~J}$, and $\mathrm{F}_{1}$ hybrid mice

\begin{tabular}{ccll}
\hline \multirow{2}{*}{$\begin{array}{l}\text { Streptozotocin } \\
\text { (mg/kg body weight) }\end{array}$} & \multicolumn{3}{l}{ Plasma glucose $(\mathrm{mmol} / \mathrm{l})$} \\
\cline { 2 - 4 } & $\mathrm{C} 3 \mathrm{H} / \mathrm{HeJ}$ & $\mathrm{C} 57 \mathrm{BL} / 6 \mathrm{~J}$ & $\mathrm{~F}_{1}$ \\
\hline 0 & $9.5 \pm 1.0$ & $11.3 \pm 1.2$ & $10.2 \pm 0.9$ \\
& $(5)$ & $(5)$ & $(5)$ \\
100 & $9.2 \pm 1.1$ & $15.7 \pm 1.3^{\mathrm{a}, \mathrm{c}}$ & $9.8 \pm 0.7$ \\
& $(6)$ & $(6)$ & $(6)$ \\
150 & $9.1 \pm 1.0$ & $19.3 \pm 3.1^{\mathrm{a}, \mathrm{c}}$ & $12.1 \pm 0.9$ \\
& $(6)$ & $(6)$ & $(6)$ \\
200 & $11.9 \pm 0.5$ & $26.3 \pm 1.5^{\mathrm{b}, \mathrm{d}}$ & $13.6 \pm 0.7$ \\
& $(6)$ & $(6)$ & $(6)$ \\
300 & $16.6 \pm 2.1$ & $29.7 \pm 2.5^{\mathrm{b}, \mathrm{c}}$ & $20.0 \pm 2.3$ \\
& $(5)$ & $(5)$ & $(5)$
\end{tabular}

Number of mice used are in parentheses. ${ }^{\mathrm{a}} p<0.05 ;{ }^{\mathrm{b}} p<0.001$ vs $\mathrm{C} 3 \mathrm{H} / \mathrm{HeJ} ;{ }^{\mathrm{c}} p<0.05{ }^{\mathrm{d}} p<0.001$ vs $\mathrm{F}_{1}$ 


\section{Results}

\section{Strain differences in $S Z$ susceptibility}

Male mice of the parental strains $\mathrm{C} 57 \mathrm{BL} / 6 \mathrm{~J}$ and $\mathrm{C} 3 \mathrm{H} / \mathrm{HeJ}$, and $\mathrm{F}_{1}$ hybrids $(\mathrm{C} 3 \mathrm{H} / \mathrm{HeJ}$ o $\circ \quad \mathrm{X}$ $\mathrm{C} 57 \mathrm{BL} / 6 \mathrm{~J}$ o $\sigma^{*}$ ) received a single injection of $\mathrm{SZ}$ ranging from 0 to $300 \mathrm{mg} / \mathrm{kg}$ body weight, and plasma glucose concentrations were determined one week later. Strain differences in the diabetogenic effects of SZ are shown in Table 1. $\mathrm{C} 3 \mathrm{H} / \mathrm{HeJ}$ and $\mathrm{F}_{1}$ mice were resistant to $\mathrm{SZ}$ at a dose of $150 \mathrm{mg} / \mathrm{kg}$ or less, while this dose produced significant hyperglycaemia in $\mathrm{C} 57 \mathrm{BL} / 6 \mathrm{~J}$ mice $(19.3 \pm 3.1 \mathrm{mmol} / 1$ vs $11.3 \pm 1.2 \mathrm{mmol} / 1, p<0.05)$. $\mathrm{SZ}$ at $200 \mathrm{mg} / \mathrm{kg}$ body weight resulted in the largest difference in plasma glucose between $\mathrm{C} 57 \mathrm{BL} / 6 \mathrm{~J}$ and $F_{1}$ hybrids (plasma glucose $26.3 \pm 1.5 \mathrm{mmol}$ vs $13.6 \pm 0.7 \mathrm{mmol} / 1$ for $\mathrm{C} 57 \mathrm{BL} / 6 \mathrm{~J}$ and $\mathrm{F}_{1}$ respectively, $p<0.001$ ).

To further define optimal conditions for observing phenotypic differences in SZ susceptibility, plasma glucose concentrations and body weights were monitored for four weeks after the injection of SZ at $200 \mathrm{mg} / \mathrm{kg}$ in each of the parental strains and in $F_{1}$ hybrids. As shown in Figure 1 , a decrease in body weight $(p<0.05)$ was observed in $\mathrm{C} 57 \mathrm{BL} / 6 \mathrm{~J}$ mice within 2 weeks after the $\mathrm{SZ}$ injection which persisted for the duration of the experiment. The mortality of $\mathrm{C} 57 \mathrm{BL} / 6 \mathrm{~J}$ mice after 4 weeks was $17 \%$ ( 1 of 6 mice). On the other hand, $\mathrm{C} 3 \mathrm{H} / \mathrm{HeJ}$ and $F_{1}$ mice gained weight and were alive four weeks after SZ injection. Hyperglycaemia in $\mathrm{C} 57 \mathrm{BL} / 6 \mathrm{~J}$ was apparent within 3 days after the injection $(p<0.001)$ and was persistent. In contrast, $\mathrm{C} 3 \mathrm{H} / \mathrm{HeJ}$ and $F_{1}$ mice appeared to be resistant to SZ, with a significant increase in plasma glucose concentration $(p<0.05)$ observed only 3 weeks or more after SZ injection. There were no differences in plasma glucose concentrations between $\mathrm{C} 3 \mathrm{H} / \mathrm{HeJ}$ and $\mathrm{F}_{1}$ mice throughout the experiment. From these findings, the plasma glucose concentration at 1 week after the injection of SZ at $200 \mathrm{mg} / \mathrm{kg}$ body weight was chosen to evaluate the genetic differences in $\mathrm{SZ}$ susceptibility.

\section{Genetic analysis of phenotypic differences in $S Z$ susceptibility}

To determine the number of genes involved in the phenotypic difference in $\mathrm{SZ}$ susceptibility, $\mathrm{F}_{1}$ mice were backcrossed with $\mathrm{C} 57 \mathrm{BL} / 6 \mathrm{~J}$ mice (Backcross: $\mathrm{F}_{1}$ 우 $\mathrm{X}$ C57BL/6J $\sigma^{*} \sigma^{*}$ ). Each male backcrossed mouse received an IPGTT and then within several days an injection of SZ (200 mg/kg body weight). Following SZ, plasma glucose measured $11.7 \pm 0.6 \mathrm{mmol} / 1 \quad(n=15)$, $26.6 \pm 1.6 \mathrm{mmol} / 1 \quad(n=15), \quad$ and $13.6 \pm 0.7 \mathrm{mmol} / 1$ $(n=15)$ for $\mathrm{C} 3 \mathrm{H} / \mathrm{HeJ}, \mathrm{C} 57 \mathrm{BL} / 6 \mathrm{~J}$, and $\mathrm{F}_{1}$ mice, respectively $\left(p<0.001, \mathrm{C} 57 \mathrm{BL} / 6 \mathrm{~J}\right.$ vs $\mathrm{C} 3 \mathrm{H} / \mathrm{HeJ}$ or $\left.\mathrm{F}_{1}\right)$. The plasma glucose concentrations after $\mathrm{SZ}$ treatment for
Table 2. Plasma glucose concentrations at 1 week after administration of a single dose of streptozotocin (SZ) $(200 \mathrm{mg} / \mathrm{kg})$ to individual backcrossed mice, and to parental strains $\mathrm{C} 57 \mathrm{BL} / 6 \mathrm{~J}$ $26.6 \pm 6.2 \mathrm{mmol} / 1$, mean $\pm \mathrm{SD}, n=15$, and $\mathrm{F}_{1}$ mice $13.6 \pm 2.7 \mathrm{mmol} / 1$, mean $\pm \mathrm{SD}, n=15$

\begin{tabular}{|c|c|c|c|c|c|}
\hline $\begin{array}{l}\text { Back } \\
\text { cross } \\
\text { mice }\end{array}$ & $\begin{array}{l}\text { Plasma } \\
\text { glucose } \\
1 \mathrm{wk} \text { after SZ } \\
\mathrm{mmol} / 1\end{array}$ & $\begin{array}{l}\text { Pheno- } \\
\text { type }\end{array}$ & $\begin{array}{l}\text { Plasma } \\
\text { glucose } \\
30 \text { min on } \\
\text { IPGTT } \\
\text { mmol/1 }\end{array}$ & $\begin{array}{l}\mathrm{GgC} \\
\text { alleles }\end{array}$ & $\begin{array}{l}\mathrm{H}-2 \\
\text { alleles }\end{array}$ \\
\hline 1 & 14.0 & $\mathrm{~F}$ & 28.9 & & \\
\hline 2 & 34.5 & B & 15.1 & B & B \\
\hline 3 & 11.3 & $F$ & 16.4 & $F$ & $\mathrm{~B}$ \\
\hline 4 & 30.3 & $\mathrm{~B}$ & 19.8 & $\mathrm{~F}$ & $\mathrm{~F}$ \\
\hline 5 & 32.6 & B & 14.5 & $F$ & $\mathrm{~B}$ \\
\hline 6 & 12.9 & $\mathrm{~F}$ & 20.2 & $F$ & $\mathrm{~F}$ \\
\hline 7 & 27.9 & B & 21.9 & & \\
\hline 8 & 13.9 & $\mathrm{~F}$ & 22.1 & & \\
\hline 9 & 14.5 & . & 26.1 & & \\
\hline 10 & 13.8 & $\mathrm{~F}$ & 27.5 & & \\
\hline 11 & 10.6 & $F$ & 19.1 & & \\
\hline 12 & 29.7 & B & 16.5 & $\mathrm{~F}$ & $\mathrm{~F}$ \\
\hline 13 & 16.0 & & 29.1 & & \\
\hline 14 & 13.0 & $\mathrm{~F}$ & 16.2 & $\mathrm{~F}$ & B \\
\hline 15 & 13.2 & $\mathrm{~F}$ & 21.2 & $\mathrm{~B}$ & $\mathrm{~F}$ \\
\hline 16 & 15.8 & & 24.3 & & \\
\hline 17 & 18.6 & & 24.8 & & \\
\hline 18 & 12.1 & $\mathrm{~F}$ & 16.7 & B & B \\
\hline 19 & 31.7 & $\mathrm{~B}$ & 17.4 & B & $\mathrm{F}$ \\
\hline 20 & 25.4 & $\mathrm{~B}$ & 23.4 & & \\
\hline 21 & 15.4 & & 22.3 & & \\
\hline 22 & 31.3 & B & 21.6 & B & $\mathrm{B}$ \\
\hline 23 & 16.1 & & 16.2 & & \\
\hline 24 & 12.5 & $F$ & 22.8 & B & $\mathrm{F}$ \\
\hline 25 & 36.0 & B & 22.3 & B & $\mathrm{F}$ \\
\hline 26 & 22.4 & B & 19.0 & & \\
\hline 27 & 28.7 & B & 15.0 & B & B \\
\hline 28 & 23.9 & $\mathrm{~B}$ & 17.4 & & \\
\hline 29 & 25.1 & B & 19.4 & & \\
\hline 30 & 20.5 & B & 20.8 & & \\
\hline 31 & 32.7 & B & 22.5 & B & \\
\hline 32 & 10.9 & $\mathrm{~F}$ & 12.8 & B & \\
\hline 33 & 27.9 & $\mathrm{~B}$ & 11.3 & & \\
\hline 34 & 12.0 & $\mathrm{~F}$ & 20.5 & $\mathrm{~F}$ & \\
\hline 35 & 16.8 & & 19.3 & & \\
\hline 36 & 10.4 & $\mathrm{~F}$ & 12.0 & B & \\
\hline 37 & 32.6 & B & 13.4 & $\mathrm{~F}$ & \\
\hline 38 & 11.3 & $F$ & 16.5 & & \\
\hline 39 & 33.4 & B & 30.7 & B & $F$ \\
\hline 40 & 15.7 & & 15.9 & & \\
\hline 41 & 31.1 & B & 17.8 & B & \\
\hline
\end{tabular}

All backcrossed mice were given an i.p. glucose tolerance test (IPGTT) one week prior to SZ as described in Methods. ${ }^{a}$ For comparison of SZ sensitivity with r-glutamyl cyclotransferase $(\mathrm{GgC})$ alleles or $\mathrm{H}-2$ alleles, individual backcrossed mice were assigned a SZ phenotype as " $B$ " if the plasma glucose after $S Z$ was greater than 2 standard deviations above the mean of the $F_{1}$ parents ( $>19.0 \mathrm{mmol} / \mathrm{l})$, or " $F$ " if less than 2 standard deviations below the mean of the $\mathrm{C} 57 \mathrm{BL} / 6 \mathrm{~J}$ parents $(<14.2 \mathrm{mmol} / \mathrm{l}) . \mathrm{GgC}$ alleles were defined as " $B$ " or " $F$ " by electrophoresis of liver protein [27], and $\mathrm{H}$ 2 alleles were defined as "B" or "F" by Southern blot analysis of DNA hybridized to $\mathrm{H}-2$ cDNA probes after identification of parental restriction length polymorphism fragments as described in Methods 

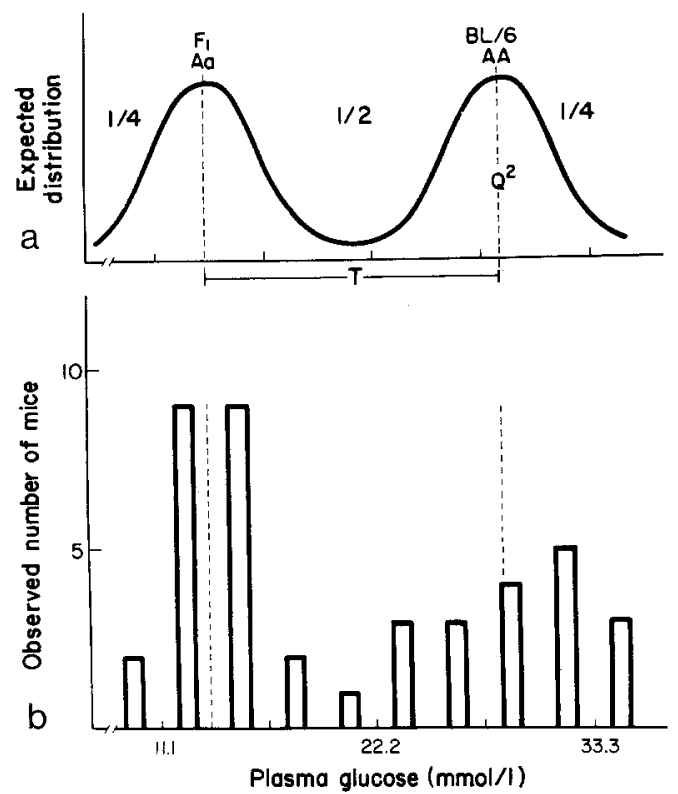

Fig. 2a and b. Population distribution patterns and chi-square analysis on the expected as a single gene (panel a) and observed (panel b) number of plasma glucose levels after streptozotocin treatment in 41 backcross mice. $\mathrm{T}$ and $\mathrm{Q}^{2}$ are SKUMIX parameters (see Table 3 ). Dotted lines represent mean (panel a) and median (panel b) values of plasma glucose levels in $\mathrm{F}_{1}$ and $\mathrm{C} 57 \mathrm{BL} / 6 \mathrm{~J}$ mice. The distribution of mice with plasma glucose below $13.3 \mathrm{mmol} / 1$ (11) between $13.3 \mathrm{mmol} / 1-28.3 \mathrm{mmol} / 1$ [18] and greater than $28.3 \mathrm{mmol} / 1$ [ [12], did not differ from expected $\left(\chi^{2}=0.66, \mathrm{df}=2, p=0.72\right)$

individual backcross mice, shown in Table 2, ranged from a low of $10.4 \mathrm{mmol} / 1$ to a high of $36.0 \mathrm{mmol} / 1$.

\section{Estimation of the number of genes controlling $S Z$ sensitivity}

If sensitivity to SZ-induced diabetes was determined by a single genetic locus, then one would expect that half of the backcross progeny would be homozygous like $\mathrm{C} 57 \mathrm{BL} / 6 \mathrm{~J}$ (AA or aa if recessive), and the other half would be heterozygous like the $F_{1}$ (Aa) mice. This would produce a mixture of two distributions, creating a bimodal distribution of the backcross progeny with one mode near each parental median. If we divide the range of glucose levels into three areas defined as above, between, and below the median values of $\mathrm{C} 57 \mathrm{BL} / 6 \mathrm{~J}$ and $\mathrm{F}_{1}$ parents, respectively, then the plasma glucose following SZ of the backcross mice would be expected to segregate in the ratio $1 / 4: 1 / 2: 1 / 4$ into these three regions. Thus, one would expect the 41 backcross progeny to segregate as $10.25: 20.5: 10.25$, whereas we observe a segregation of 11:18:12 (Fig. 2b). This yields a $\chi^{2}$ of 0.66 with $2 \mathrm{df}$ which is not significant $(p=0.72)$. Therefore, on the basis of this analysis, the data are compatible with the hypothesis of a single gene control.

On the other hand, the simple $\chi^{2}$ analysis only counts the number of points in each of the three regions, and is, therefore, ignoring much of the information contained in the continuous variation observed in actual glucose levels. For instance, if glucose levels were really under polygenic control, a unimodal distribution, in which most of the data would be between the two parental median values and fewer in the extreme regions, would be expected. If this polygenic distribution , were non-normal, with particularly "fat tails" or skewed distribution, it could also show segregation proportions of nearly $1 / 4: 1 / 2: 1 / 4$.

To allow for this possibility, and to attempt to use all of the information available in the backcross mice data, we tested whether the data were significantly better explained as a bimodal mixture of two distributions (as expected if there is a single gene control) or whether a single, unimodal, possibly skewed distribution fitted the data better (as expected if the phenotype were under polygenic control). The program used was SKUMIX [26], and the results of this analysis are shown in Table 3. For each line of Table 3, six parameters are fitted by the method of maximum likelihood (Figure 2a): the overall mean (U) and variance (V) of the mixed distribution, the distance $(\mathrm{T})$ between the means of the two distributions, the proportion of data in the rightmost distribution $\left(Q^{2}\right)$, and two parameters of a power transformation ( $\mathrm{P}$ and $\mathrm{R}$ ) applied to each component distribution to more closely transform the data to normality. Finally for each model, -2 times the loglikelihood is given $(-2 \ln \mathrm{L})$. For the general two-distribution model (Line 1 of Table 3 ), $\mathrm{Q}^{2}$ is far from 0 or 1 , indicating two distributions; $T$ is large, indicating good separation of them and in fact $Q^{2}$ is nearly $1 / 2$, which is what is expected if half of the backcross mice resemble

Table 3. Analysis of SKUMIX parameters

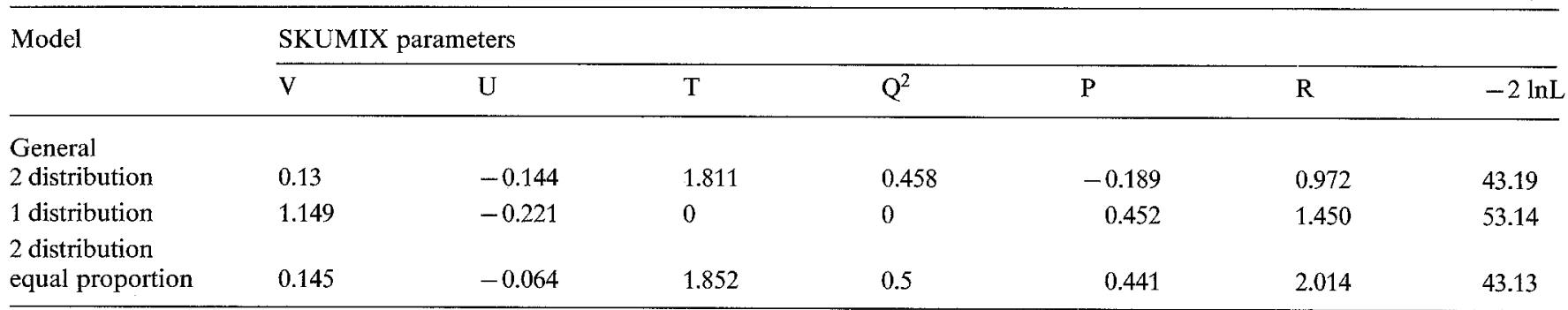

Parameters were fitted by the method of maximum likelihood for each model. V: overall variance; U: overall mean; T: distance between the two means; $\mathrm{Q}^{2}$ : proportion in right distribution (see Fig. 2); P and R: power transform parameters; -2 lnL: -2 times the log-likelihood 


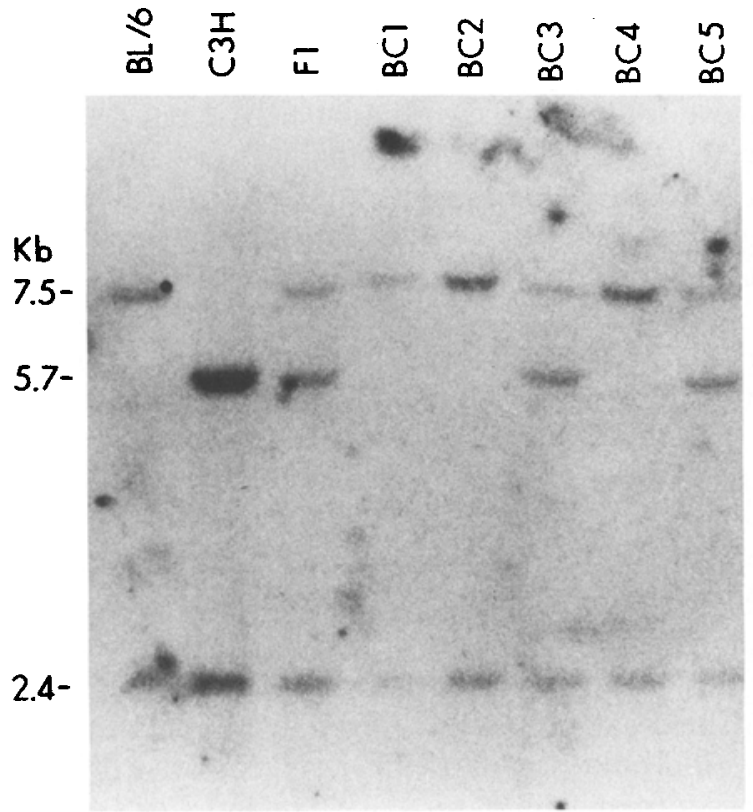

Fig.3. Southern blot analysis of DNA restriction fragment length polymorphism of the parental strains, $\mathrm{C} 57 \mathrm{BL} / 6 \mathrm{~J}$ and $\mathrm{C} 3 \mathrm{H} / \mathrm{HeJ}$, and the $F_{1}$ progeny and the backcross (backcross: $F_{1} X$ C57BL/6J) mice digested with the restriction endonuclease Taq I and hybridized with ${ }^{32}$ P-labelled A probe for the $\mathrm{H}-2$ locus as described in Methods. All backcross mice were either homozygous for the C57BL/6J 5.7 kilobase $(\mathrm{kb})$ fragment, or heterozygous for the $F_{1} 7.5 \mathrm{~kb}$ and $5.7 \mathrm{~kb}$ fragments. Fifteen backcross mice used in this experiment were chosen from 41 backcross mice by their glucose levels after streptozotocin treatment as shown in Table 2 . Results for 5 out of 15 backcross mice studied are illustrated

each of their parents. If there is just one distribution, then $\mathrm{T}=0$ and $\mathrm{Q}^{2}=0$, which we have tested in the second line of Table 3. Subtracting the $-2 \ln L$ sives a $\chi^{2}$ of $9.95,2 \mathrm{df}, p=0.007$. Thus, two distributions fit significantly better than one, even allowing for skewness ( $P$ and $\mathrm{R}$ ). On the other hand, allowing two distributions, but fixing the proportion at $\mathrm{Q}^{2}=1 / 2$ as in the last line, gives a $\chi^{2}$ of only 0.06 compared to the general model $(p=0.81)$. Thus, the fit is not significantly different from the one forcing equal proportions of the two component distributions. The evidence from both tests would seem to indicate a single gene involvement in the expression of phenotype for hyperglycaemia after SZ treatment of $\mathrm{C} 57 \mathrm{BL} / 6 \mathrm{~J}$ mice.

\section{$S Z$ susceptibility in $B x H$ recombinant inbred strains}

The recombinant inbred (RI) strain $\mathrm{BxH}$, originally generated from $\mathrm{C} 57 \mathrm{BL} / 6 \mathrm{~J}$ and $\mathrm{C} 3 \mathrm{H} / \mathrm{HeJ}$ inbred strains and maintained by the Jackson Laboratories for more than 30 generations, was utilized for further genetic analysis of susceptibility to SZ-induced diabetes. The utility of RI strains for purposes of genetic analysis has been described [23]. RI strains are produced by random sibling mating of the $F_{2}$ generation, and subsequent separation and breeding of each
RI strain until homozygosity is obtained at each locus. Because of inbreeding, each RI strain is homozygous for alleles at a given locus from one parent. If $\mathrm{SZ}$ sensitivity were controlled by a single locus, then SZ-sensitivity in RI rats should resemble that of one of the parent strains. Intermediate values would argue for more than a single locus.

The plasma glucose concentrations 1 week after SZ treatment were determined in 5-6 mice of each of the 12 available BxH RI strains (Table 4). Only one strain $(\mathrm{BxH}-2)$ resembled the $\mathrm{C} 3 \mathrm{H} / \mathrm{HeJ}$ progenitor with resistance to $\mathrm{SZ}$, while the remaining 11 strains showed higher levels of plasma glucose resembling the $\mathrm{C} 57 \mathrm{BL} / 6 \mathrm{~J}$ progenitor. The plasma glucose concentrations of 11 of the RI strains (BxH-3 to 19) did not differ from each other or from the $\mathrm{C} 57 \mathrm{BL} / 6 \mathrm{~J}$ parental strain (unpaired $t$-test), yet were significantly higher than those of the $\mathrm{C} 3 \mathrm{H} / \mathrm{HeJ}$ parental strain and $\mathrm{BxH}-2$ mice $(p<0.001)$. The glucose level of $\mathrm{BxH}-2$ mice was significantly lower than that of the $\mathrm{C} 57 \mathrm{BL} / 6 \mathrm{~J}$ progenitor $(p<0.001)$. These observations provided additional evidence that the difference in SZ susceptibility in the parental strains is mostly the result of a single major gene.

\section{Evaluating the major locus controlling $S Z$ susceptibility relative to other loci}

We previously demonstrated a marked difference in glucose tolerance between these two strains and that this phenotypic difference was determined by multiple genetic loci [24]. To determine the relationship between these loci and the major locus which controls susceptibility to SZ-induced diabetes, each backcross: $\mathrm{F}_{1} \mathrm{X}$

Table 4. Hyperglycaemic response after a single injection of streptozotocin $(200 \mathrm{mg} / \mathrm{kg})$ in $12 \mathrm{BxH}$ recombinant inbred strains

\begin{tabular}{lll}
\hline Strains & Plasma glucose $(\mathrm{mmol} / \mathrm{l})$ & Phenotype \\
\hline Parental & & \\
C3H/HeJ & $11.9 \pm 0.5(15)$ & $\mathrm{H}$ \\
C57BL/6J & $26.3 \pm 1.5(15)$ & $\mathrm{B}$ \\
Recombinant inbred & & \\
BxH-2 & $10.8 \pm 1.1^{\mathrm{b}}(5)$ & $\mathrm{H}$ \\
BxH-3 & $20.0 \pm 2.8^{\mathrm{a}}(5)$ & $\mathrm{B}$ \\
BxH-4 & $21.3 \pm 2.8^{\mathrm{a}}(5)$ & $\mathrm{B}$ \\
BxH-6 & $25.7 \pm 2.9^{\mathrm{a}}(6)$ & $\mathrm{B}$ \\
BxH-7 & $24.9 \pm 3.6^{\mathrm{a}}(6)$ & $\mathrm{B}$ \\
BxH-8 & $23.6 \pm 4.1^{\mathrm{a}}(6)$ & $\mathrm{B}$ \\
BxH-9 & $27.0 \pm 2.8^{\mathrm{a}}(6)$ & $\mathrm{B}$ \\
BxH-10 & $23.4 \pm 3.5^{\mathrm{a}}(5)$ & $\mathrm{B}$ \\
BxH-11 & $21.3 \pm 3.1^{\mathrm{a}}(5)$ & $\mathrm{B}$ \\
BxH-12 & $26.2 \pm 2.8^{\mathrm{a}}(5)$ & B \\
BxH-14 & $21.8 \pm 3.1^{\mathrm{a}}(5)$ & B \\
BxH-19 & $27.8 \pm 1.3^{\mathrm{a}}(5)$ & $\mathrm{B}$ \\
\hline
\end{tabular}

Values indicated are mean \pm SEM. Number of mice are in parentheses. ${ }^{\mathrm{a}} p<0.001$ vs $\mathrm{C} 3 \mathrm{H} / \mathrm{HeJ} ;{ }^{b} p<0.001$ vs $\mathrm{C} 57 \mathrm{BL} / 6 \mathrm{~J}$ 
C57BL/6 mouse was given an IPGTT several days prior to SZ. The plasma glucose levels at $30 \mathrm{~min}$ on IPGTT for the parental strains and $F_{1}$ hybrids were readily distinguishable with plasma glucose concentrations of $12.2 \pm 0.9 \mathrm{mmol} / 1 \quad(n=6), 26.3 \pm 2.2 \mathrm{mmol} / 1$ $(n=6)$, and $15.9 \pm 1.0 \mathrm{mmol} / 1 \quad(n=6)$ for $\mathrm{C} 3 \mathrm{H} / \mathrm{HeJ}$, $\mathrm{C} 57 \mathrm{BL} / 6 \mathrm{~J}$, and $\mathrm{F}_{1}$ mice, respectively $(p<0.001$ for all comparisons), confirming the previous report [24]. The glucose levels of 41 backcross mice ranged in a continuum of values from a low of $11.3 \mathrm{mmol} / 1$ to a high of $30.7 \mathrm{mmol} / 1$ (Table 2). Analysis of this data by methods used to evaluate SZ sensitivity (i. e. comparing the number of values in backcross mice below, between, and above the median values for $\mathrm{C} 57 \mathrm{BL} / 6 \mathrm{~J}$ and $\mathrm{F}_{1}$ parental strains) allowed rejection of a single gene hypothesis with a high degree of probability $\left(\chi^{2}=21.3, \mathrm{df}=2\right.$, $p<0.001$ ), again confirming the previous report [24]. Although the phenotypic patterns for SZ sensitivity corresponded to those for glucose tolerance in the parental strains, no correlation was observed between SZ sensitivity and glucose tolerance in individual backcrossed mice $(r=0.13)$.

The strain distribution pattern of SZ sensitivity in the BxH RI mice was compared to the strain distribution pattern of 95 phenotypic markers previously mapped in the BxH RI lines (provided by Dr. Ben Taylor, The Jackson Laboratories, Bar Harbor, Me, USA). The strain distribution pattern for SZ-sensitivity in the $\mathrm{BxH}$ RI lines most nearly resembled the pattern of $\mathrm{r}$ glutamyl cyclotransferase alleles (Ggc) on chromosome 6 . For this reason the Ggc enzymic forms of the backcross progeny were determined using agarose gel electrophoresis of the liver protein following the method of Tulchin and Taylor [27], and Ggc alleles compared to SZ-sensitivity. For this analysis, backcross mice were either designated $\mathrm{SZ}$ sensitive $(\mathrm{C} 57 \mathrm{BL} / 6 \mathrm{~J}$ like or "B") if plasma glucose following SZ was > 2 SD above the mean of the $F_{1}$ response, or designated $S Z$ resistant $\left(F_{1}\right.$-like or " $F$ ") if plasma glucose following $\mathrm{SZ}$ was $<2 \mathrm{SD}$ below the mean of the response in C57BL/6J mice (see Table 2). Recombination between the Ggc locus and the locus for SZ sensitivity occurred in 9 of 21 backcross progeny examined for the Ggc enzymic forms indicating lack of tight linkage of the two loci. Therefore SZ-sensitivity could not be mapped in the BxH RI strains by strain distribution pattern with known markers.

To evaluate possible involvement of the $\mathrm{H}-2$ locus in susceptibility to SZ-induced diabetes, the $\mathrm{H}-2$ genotypes of the parental mouse strains were initially determined by identifying RFLPs in parental DNA. DNA was digested with eight different restriction endonucleases, and RFLPs which distinguished the parental DNAs were observed with an A $\alpha$ genomic probe in Hind III, Pvu II or Taq I digested DNA, and with an $\mathrm{E}_{\beta 2}$ genomic probe in Apa I digested DNA. The H-2 genotype was then defined in each of 15 individual backcross progeny. Results of an analysis of Taq I
RFLPs are shown in Table 2 and Figure 3. All backcross mice were either homozygous for the C57BL/6J 5.7 kilobase $(\mathrm{kb})$ fragment, or heterozygous for the $F_{1}$ $7.5 \mathrm{~kb}$ and $5.7 \mathrm{~kb}$ fragments. Recombination between the $\mathrm{H}-2$ locus and SZ sensitivity was present in 8 of 15 backcrossed progeny evaluated, indicating random association of these loci and lack of tight linkage.

\section{Discussion}

The differences in sensitivity to SZ-induced diabetes in $\mathrm{C} 57 \mathrm{BL} / 6 \mathrm{~J}$ and $\mathrm{C} 3 \mathrm{H} / \mathrm{HeJ}$ mice noted in this study were in general consistent with those of a previous report [3]. The plasma glucose concentration one week after the administration of a single dose of $\mathrm{SZ}$ in $\mathrm{F}_{1}$ hybrids relative to that in $\mathrm{C}_{57} \mathrm{BL} / 6 \mathrm{~J}$ provided the clearly distinguished parental phenotypes required for the genetic analysis in the current study. Plasma glucose concentrations of backcross $\left(\mathrm{F}_{1} \times \mathrm{C} 57 \mathrm{BL} / 6 \mathrm{~J}\right)$ mice appeared to segregate into two populations, half like the C57BL/6J parent, and half like the $F_{1}$ parent, and it was concluded that in these two strains SZ susceptibility is predominantly determined by different alleles at a single major locus. This hypothesis was also supported by the observation that the response to $\mathrm{SZ}$ treatment in the $\mathrm{BxH} \mathrm{RI}$ strains could be divided into two classes (Table 4). In addition, the results in the $F_{1}$ hybrids suggest that the SZ susceptible allele is recessive, although X-chromosome linked inheritance cannot be excluded, because only male $F_{1}$ mice were studied. An X-linked factor could be evaluated in crosses of $\mathrm{C} 57 \mathrm{BL} / 6 \mathrm{~J}$ females and $\mathrm{C} 3 \mathrm{H} / \mathrm{HeJ}$ males by defining the SZ-sensitivity of these $\mathrm{F}_{1}$ hybrids. Studies have noted variable susceptibility to SZ-induced diabetes in other inbred strains [1-4, 18-20], and our findings in $\mathrm{C} 57 \mathrm{BL} / 6 \mathrm{~J}$ and $\mathrm{C} 3 \mathrm{H} / \mathrm{HeJ}$ mice do not exclude the possibility that different loci may be involved in other inbred strains, or that multiple alleles for SZ sensitivity may exist at the same locus.

The data on SZ sensitivity in the RI strains provides support for a single major gene, yet the data is not compelling. While the response to SZ in one strain (Table 4, $\mathrm{BxH}-2$ ) clearly resembled that in the $\mathrm{C} 3 \mathrm{H} / \mathrm{HeJ}$ parental strain, it is not so clear that the response in all other $\mathrm{BxH}$ strains was not different from that in the $\mathrm{C} 57 \mathrm{BL} / 6$ parental strain. The variation in responses to $\mathrm{SZ}$ in the $\mathrm{BxH}$ strains was such that if larger numbers had been evaluated, significant differences from the C57BL/6J parents may have been noted. This would suggest additional minor loci which influence SZ susceptibility. An important test of the single gene hypothesis would be the analysis of SZ-sensitivity in $\mathrm{F}_{1}$ hybrids of $\mathrm{BxH}-2$ and one or more of the 11 SZ-sensitive BxH-RI strains, and in backcrosses of $F_{1}$ hybrids to the sensitive parental LBxH-RI strains. This genetic analysis has not been undertaken, however, and cannot be done in the immediate future due to the recent lack of availability of these mice from the Jackson Laboratories. 
Only two loci have been tested for linkage to the locus for SZ sensitivity. Using the strain distribution pattern for SZ-sensitive and resistant alleles in the set of BxH RI strains, the locus was estimated to be linked to the $\mathrm{GgC}$ locus on chromosome 6. However, direct observation of $\mathrm{GgC}$ alleles in the backcross progeny showed a random association between $\mathrm{SZ}$ sensitivity and the $\mathrm{GgC}$ locus. Silver and Bucker noted that the usual statistical analysis for gene mapping using RI strains may lead to incorrect conclusions about linkage unless unusually stringent criteria are adopted for rejecting the null hypothesis [28]. Only $12 \mathrm{BxH}$ strains are available, and the present observations clearly demonstrate that gene mapping with a small number of RI strains may lead to an erroneous conclusion.

The second locus tested for linkage was the $\mathrm{H}-2$ locus. The $\mathrm{H}-2$ genotypes in the backcross mice were identified using RFLPs at this locus (Figure 3), and the results showed lack of tight linkage. Interestingly, Leiter has recently shown lack of linkage of susceptibility to multiple low-dose injections of SZ with the $\mathrm{H}-2$ locus in $\mathrm{C} 57 \mathrm{BL} / \mathrm{KsJ}$ and $\mathrm{C} 57 \mathrm{BL} / 6 \mathrm{~J}$ mice [22].

The metabolic events involved in SZ-induced pancreatic B-cell necrosis and diabetes are not well understood, and one can only speculate as to the nature of the genetic locus defining SZ sensitivity in $\mathrm{C} 3 \mathrm{H} / \mathrm{HeJ}$ and $\mathrm{C} 57 \mathrm{BL} / 6 \mathrm{~J}$ mice. Kawada et al. recently reported that a non-metabolizable SZ analogue was a potent as SZ in its diabetogenic effect [29], suggesting that an important event in SZ diabetes is interaction of the drug with a specific glucose recognition site on pancreatic B cells. In previous studies, a marked difference in glucose-stimulated insulin release was noted to account for at least part of the difference in glucose tolerance between $\mathrm{C} 57 \mathrm{BL} / 6 \mathrm{~J}$ and $\mathrm{C} 3 \mathrm{H} / \mathrm{HeJ}$ mice [24], which suggested that the difference in SZ sensitivity might reflect a difference in pancreatic B-cell glucose recognition. Yet in the current study, there was no correlation between glucose tolerance and $\mathrm{SZ}$ sensitivity in the backcross mice (Table 2).

Two candidate genetic loci for SZ-susceptibility in mice may be relevant to the genetic susceptibility to diabetes in man. If SZ exerts its cytotoxic action on pancreatic B cells by lowering intracellular levels of NAD through SZ-induced activation of poly (ADP-ribose) synthetase [30-33], then the SZ-sensitivity locus may code for different alleles for this enzyme. On the other hand, allelic differences in metabolism of nitrosurea compounds may be linked to cytochrome $\mathrm{p} 450$ genes in mice [34-36]. Genetic analysis with cloned gene probes for these loci will define the relationship of these loci to SZ-induced diabetes in mice. If chronic exposure to nitrosurea compounds contributes to diabetes in man, then identification of the major locus responsible for differences in sensitivity in mice may provide a means to assess a putative homologous locus in man.

Acknowledgements. We thank Ms. C. Welling for her technical assistance and Ms. J. Wokurka for help in preparation of the manuscript.
The mouse $\mathrm{H} 2$ genomic DNA probes and strain distribution pattern of the BxH RI lines were kindly provided by Dr. E. Leiter of the Jackson Laboratories. This work was supported by Juvenile Diabetes Foundation Grant 386311 and by NIH Grant AM16746.

\section{References}

1. Junod A, Lambert AE, Orci L, Piltet R, Gonet AE, Renold AE (1967) Studies of the diabetogenic action of streptozotocin. Proc Soc Exp Biol Med 129: 201-205

2. Like AA, Rossini AA (1976) Streptozotocin-induced pancreatic insulitis; new model of diabetes mellitus. Science 193:415-417

3. Rossini AA, Appel MC, Williams RM, Like AA (1977) Genetic influence of the streptozotocin-induced insulitis and hyperglycemia. Diabetes 26: 916-920

4. Like AA, Appel MC, Williams RM, Rossini AA (1978) Streptozotocin-induced pancreatic insulitis in mice. Morphologic and physiologic studies. Lab Invest 38: 470-486

5. Lewis C, Barbiers AR (1959) Streptozotocin, a new antibiotic. In vitro and in vivo evaluation. Antibiot Ann pp 247-254

6. Varva JJ, DeBoer C, Dietz A, Hanka LJ, Sokolski WJ (1959) Streptozotocin, a new antibacterial antibiotic. Antibiot Ann pp 230-235

7. White FR (1963) Streptozotocin. Cancer Chemother Rep 30: 49-53

8. Rakieten N, Rakieten ML, Nadkarni MV (1963) Studies of the diabetogenic action of streptozotocin (NSC-37917). Cancer Chemother Rep 29: 91-98

9. Lown JW, McLaughlin LW, Chang Y-M (1978) Mechanism of action of 2-haloethyl nitrosoureas on DNA and its relation to their antileukemic properties. Bioorg Chem 7:97-110

10. Dulin WE, Wyse BM (1969) Studies of the ability of compounds to block the diabetogenic activity of streptozotocin. Diabetes 18: 459-466

11. Shein PS, Cooney DA, Vernon ML(1967) The use of nicotinamide to modify the toxicity of streptozotocin diabetes without loss of antitumoral activity. Cancer Res 27: 2324-2332

12. Anderson T, Shein PS, McMenamin MG (1974) Streptozotocin diabetes. Correlation with extent of depression of pancreatic islet nicotinamide adenine dinucleotide. J Clin Invest 54: 672-677

13. Leiter EH (1985) Differential susceptibility of BALB/c sublines to diabetes induction by multi-dose streptozotocin treatment. Curr Top Microbiol Immunol 122: 78-85

14. Rossini AA, Williams RM, Appel MC, Like AA (1978) Sex differences in the multiple-dose streptozotocin model of diabetes. Endocrinology 103: 1518-1520

15. Maclaren NK, Neufeld M, McLaughlin JV, Taylor G (1980) Androgen sensitization of streptozotocin-induced diabetes in mice. Diabetes 29: 710-716

16. Paik S, Michelis MA, Kim YT, Shin S (1982) Induction of insulindependent diabetes by streptozotocin: inhibition by estrogens and potentiation by androgens. Diabetes 31: 724-729

17. Kiesel U, Kolb M (1982) Low-dose streptozotocin-induced autoimmune diabetes is under the genetic control of the major histocompatibility complex in mice. Diabetologia $23: 69-71$

18. Kiesel U, Falkenberg FW, Kolb H (1983) Genetic control of lowdose streptozotocin-induced autoimmune diabetes in mice. J Immunol 130: 1719-1722

19. Wolf J, Lilly F, Shin S (1984) The influence of genetic background on the susceptibility of inbred mice to streptozotocin-induced diabetes. Diabetes 33: 567-571

20. Le PH, Leiter EH, Leyendecker JR (1985) Genetic control of susceptibility to streptozotocin diabetes in inbred mice: effect of testosterone and H-2 haplotype. Endocrinology 116: 2450-2455

21. Kromann H, Christy M, Egeberg J, Lernmark Å, Nerup J (1982) Absence of $\mathrm{H}-2$ genetic influence on streptozotocin-induced diabetes in mice. Diabetologia 23:114-118

22. Leiter EH, Le PH, Coleman DL (1987) Susceptibility to db gene and streptozotocin-induced diabetes in C57/BL mice: control by gender-associated, MHC-unlinked traits. Immunogenetics 26: 6-13 
23. Bailey DW (1981) Recombinant inbred strains and bilineal congenic strains. In: Foster HL, Small JD, Fox JF (eds) The mouse in biomedical research, Vol I. Academic Press, New York, pp 223-239

24. Kaku K, Fiedorek FT Jr, Province M, Permutt MA (1988) Genetic analysis of glucose tolerance in inbred strains of mice: evidence for polygenic control. Diabetes 37: 707-713

25. Passmore HC, Kobori JA, Zimmerer EJ, Spinella DG, Hood L (1987) Molecular characterization within the major histocompatibility complex of the mouse: mapping of crossover sites within the I region. Biochem Genetics 25: 513-523

26. Morton NE, Rao DC, Lalouel JM (1983) Methods in genetic epidemiology. Karger, Basle New York Tokyo Sydney, pp 21-23

27. Tulchin N, Taylor BA (1981) r-glutamyl cyclotransferase: a new genetic polymorphism in the mouse (mus musculus) linked to LYT-2. Genetics 99: 109-116

28. Silver J, Buckler CE (1986) Statistical considerations for linkage analysis using recombinant inbred strains and backcrosses. Proc Natl Acad Sci USA 83: 1423-1427

29. Kawada J, Toide K, Nishida M, Yoshimura Y, Tsujihara K (1986) New diabetogenic streptozotocin analogue, 3-0-methyl-2$\{[$ (methyl-nitrosamino) carbonyl] amide\}-D-glucopyranose. Evidence for a glucose recognition site on pancreatic B-cells. Diabetes 35: 74-77

30. Cooperstein SJ, Watkins D (1981) Action of toxic drugs on islet cells. In: Cooperstein SJ, Watkins D (eds) The islets of Langerhans. Academic Press, New York, pp 387-425

31. Okamoto H (1981) Regulation of proinsulin synthesis in pancreatic islets and a new aspect to insulin-dependent diabetes. Mol Cell Biochem 37: 43-61
32. Yamamoto $H$, Uchigata $Y$, Okamoto $H$ (1981) Streptozotocin and alloxan induce DNA strand breaks and poly(ADP-ribose) synthetase in pancreatic islets. Nature 294: 284-286

33. Yamamoto H, Uchigata Y, Okamoto H (1981) DNA strand breaks in pancreatic islets by in vivo administration of alloxan or streptozotocin. Biochem Biophys Res Comm 103: 1014-1020

34. Rouer E, LeProvost E, Leroux J-P (1983) Study of benzphetamine$\mathrm{N}$-demethylase in streptozotocin-diabetic mice and rats: evidence of the induction of catalytically and immunologically specific forms of cytochrome $\mathrm{p} 450$. Biochim 65: 679-683

35. Peng R, Tennant P, Lorr NA, Yang CS (1983) Alterations of microsomal monooxyganase system and carcinogen metabolism by streptozotocin-induced diabetes in rats. Carcinogenesis 4: 703-708

36. Favreau LV, Schenkman JB (1988) Composition changes in hepatic microsomal cytochrome p-450 during onset of streptozotocin-induced diabetes and during insulin treatment. Diabetes 37 : $577-584$

Received: 29 December 1988

and in final revised form: 17 July 1989

\section{Dr. K. Kaku}

Metabolism Division

Department of Internal Medicine

Washington University School of Medicine

660 S. Euclid

St. Louis, MO 63110

USA 